IZA DP No. 7927

The Effect of Wealth and Earned Income on the Decision to Retire:

A Dynamic Probit Examination of Retirement

Keith A. Bender

Kostas Mavromaras

loannis Theodossiou

Zhang Wei

January 2014 


\title{
The Effect of Wealth and Earned Income on the Decision to Retire: A Dynamic Probit Examination of Retirement
}

\author{
Keith A. Bender \\ CELMR, University of Aberdeen
}

Kostas Mavromaras

NILS, Flinders University and IZA

Ioannis Theodossiou

CELMR, University of Aberdeen

Zhang Wei

NILS, Flinders University

Discussion Paper No. 7927
January 2014

IZA
P.O. Box 7240
53072 Bonn
Germany

Phone: +49-228-3894-0

Fax: +49-228-3894-180

E-mail: iza@iza.org

\begin{abstract}
Any opinions expressed here are those of the author(s) and not those of IZA. Research published in this series may include views on policy, but the institute itself takes no institutional policy positions. The IZA research network is committed to the IZA Guiding Principles of Research Integrity.

The Institute for the Study of Labor (IZA) in Bonn is a local and virtual international research center and a place of communication between science, politics and business. IZA is an independent nonprofit organization supported by Deutsche Post Foundation. The center is associated with the University of Bonn and offers a stimulating research environment through its international network, workshops and conferences, data service, project support, research visits and doctoral program. IZA engages in (i) original and internationally competitive research in all fields of labor economics, (ii) development of policy concepts, and (iii) dissemination of research results and concepts to the interested public.
\end{abstract}

IZA Discussion Papers often represent preliminary work and are circulated to encourage discussion. Citation of such a paper should account for its provisional character. A revised version may be available directly from the author. 


\section{ABSTRACT}

\section{The Effect of Wealth and Earned Income on the Decision to Retire: A Dynamic Probit Examination of Retirement}

This paper estimates the propensity to retire and the persistence of remaining retired once the decision to retire has been made in the US labour market, using a dynamic panel probit model. The estimated income effect of higher housing wealth is virtually zero and that of financial assets wealth is positive, increasing the retirement probability. The substitution effect of earned income is negative, thus decreasing the retirement probability. The retirement decision is strongly state persistent for up to three years after the initial retirement decision and the state persistence of retirement is reinforced by wealth and earned income.

JEL Classification: J14, J26

Keywords: retirement decision, retirement dynamics, dynamic panel estimation, income and wealth

Corresponding author:

Kostas Mavromaras

National Institute of Labour Studies

Flinders University

GPO Box 2100

Adelaide, South Australia 5001

Australia

E-mail: k.mavromaras@flinders.edu.au 


\section{INTRODUCTION}

With the leading edge of the Baby Boom Generation entering into the traditional retirement ages, developed countries are facing unprecedented challenges in the financing of public pensions and health care. These challenges are motivating serious discussion on the modification of these programs to balance the well-being of (the potentially vulnerable) individual retirees with public finances. However, beyond these challenges, we are observing fundamental changes in retirement patterns across countries. In the event that these changes might affect the balance between individual and corporate well-being, research on retirement patterns is necessary to inform any proposed changes in these public retirement programs.

One important change that has been documented in the last 30 years is that 'retirement' is increasingly becoming a gradual process rather than a full withdrawal from the labour force. Furthermore, unanticipated shocks, such as the substantial decreases in financial assets during the recession of the late 2000s and early 2010s, are seemingly able to push some retirees who were not working, back into the labour force. While there have been a few papers that have started to examine the re-entry of retirees back into work, this area of the literature is still in its early stages of development and is generally descriptive in nature.

This paper sets out to examine retirement patterns using panel data over sixteen years. Unlike the previous literature on retirement transitions or re-employment, we estimate a retirement propensity and persistence model using a dynamic probit regression to not only identify the propensity and persistence of retirement over time, but also to see if this persistence varies by key characteristics of retirees, in particular, paid employment income, housing wealth and financial assets. In as much as these characteristics are influenced by public policy and economic conditions, understanding whether their changes affect the 
persistence of retirement can help inform proposals of retirement policy reform. The paper finds that retirement decisions are in no shape or form final, with a large proportion of retirees returning to employment after their initial retirement. Whilst both higher levels of housing wealth and financial assets appear to make retirement more likely, it is mainly the more liquid financial assets that have an effect on the timing of retirement. Higher paid employment income makes retirement less likely in a more influential way than either of the two measures of wealth. The paper finds that retirement is a persistent state and that this persistence is almost unaffected by higher wealth and reduced by higher paid employment income.

\section{BACKGROUND}

As far as we know, there is no research directly investigating the 'persistence' of retirement. However, there are several related literatures that help inform the research - namely research on the determinants of retirement and employment patterns of retirement age workers. Each literature is large and is beyond the scope of the present paper to review. However, the discussion below gives a general flavour of the research and suggests important considerations for the analysis.

\subsection{Determinants of Retirement}

Economists have found a variety of factors that affect retirement behaviour and these determinants spring from a variety of ways of modelling the retirement decision (see, for example, Mitchell and Fields, 1984; Rust, 1989; and Gustman and Steinmeier, 1986). Important in all models are the economic incentives for retirement from both earnings, which gives the shadow price of leisure, and wealth, which generates an income effect. In the latter case, many forms of wealth have been considered including public pension wealth (e.g. 
Vanderhart, 2003, and Hanel, 2010) and private pension wealth (Gustman et al., 1994, and Samwick, 1998).

Early research considered labour force participation and retirement as a separate economic decision resulting from an outcome of optimal consumption and savings behaviour (Bowen and Finigan, 1969, and Feldstein, 1974). They explain the decline of the labour force participation of the older workers as an outcome of mandatory retirement, preferences for leisure, health status, eligibility and availability of retirement benefits. However, Quinn (1977) and Boskin and Hurd (1978) consider health as one of the main determinants of labour force status in addition to wages and retirement benefits and that the effect of retirement benefit levels on early retirement is large and positive. Feldstein (1974) develops a life cycle framework to show that current income levels explain only a part of the retirement patterns. Future income expectations appear to have a substantial impact on the retirement decision. Furthermore, Sheshinski (1978) shows that the replacement ratio (the ratio of benefits to wages) significantly affect early retirement and that rises in benefits reduce lifetime savings. Crawford and Lilien (1981) trace the high incidence of earlier retirement to high replacement ratios regimes.

Burkhauser (1979) models the decision to retire using the difference between early and normal pension benefits as explanatory factor and found that this depends on the age specific actuarial value of the individuals pension plan and not on payments in anyone year. Moreover, Burkhauser (1980) finds that the entire stream of future earnings and not annual values, was a major determinant of early retirement. However, Gordon and Blinder (1980) finds that future income turned out to be a major determinant of early retirement model, and, contrary to Burkhauser (1980), only weak effects of Social Security on early retirement 
decision are found. Finally, Fields and Mitchell (1984a) explain retirement age by current and future streams of earnings, private pensions and Social Security benefits. Their results show that the age of retirement ages is sensitive to anticipated income opportunities. The authors argue that for each retirement age, there is a separate future benefit stream and that the individual makes the retirement decision by comparing different future benefit stream. Fields and Mitchell (1984b) find that reduced benefits at early ages and increased rewards for continued employment result in delaying the age of retirement. Overall, income opportunities vary largely between pension plans, and those differences significantly affect retirement patterns. Finally, Diamond and Hausman (1984) argue that unexpected events can seriously disrupt the retirement plans of even far sighted workers. To illustrate this they explicitly allow for uncertainty to be an element of the decision process. Their results show that pension values and Social Security benefits significantly affect the probability of retirement. These results are confirmed by Hausman and Wise (1985). Anderson et al. (1986) and Burtless (1986) address the issue of uncertainty by investigating the effect of unanticipated changes in economic circumstances on initial retirement plans and found that unanticipated increases in Social Security wealth and unexpected health deterioration have a positive and significant effect on the probability of earlier retirement. Interestingly and conversely, Coile and Levine (2006) find that unanticipated wealth shocks in terms of stock market fluctuations seem to have little effect on labour force participation.

Heyma (2004) shows that the main determinants of retirement decisions are income, absolute preferences for leisure time and health. Preferences for retirement income dominate preferences for earnings. Compared to male workers, female workers retire sooner and partners take joint retirement decisions. The influence of health on retirement decisions is 
significant. If health deteriorates, preferences for retirement grow and people in bad health prefer immediate retirement over income.

Other research identifies key determinants in the retirement decision, including nonwage benefits (Lumsdaine et al. 1997 and Fronstin, 1999), health (e.g. Hausman and Wise, 1985; Heyma, 2004; French, 2005; and Garcia-Gomez et al. 2010), and joint retirement decisions of households (e.g. Gustman and Steinmeier, 2000, Heyma, 2004; and Kapur and Rogowski, 2007).

\subsection{Employment Patterns of Retirement Age Workers}

The literature has two distinct directions regarding employment patterns of retirement age workers. The first is a mostly older literature (e.g. Gustman and Steinmeier, 1984; Ruhm, 1990; and Quinn and Burkhauser, 1990) that examines so-called, 'bridge jobs', as a way of an intentional reduction in labour force attachment approaching retirement. Quinn (1996) suggests, though, that these transitional jobs are the result of contradictory policies from the public sector and employers, since public pensions can give delayed retirement credits to promote longer employment, while firms are often eager to sever the employment relationship with older and, thus, more expensive workers. More current research (e.g. Quinn and Kozy, 1995; Cahill et al., 2005; Zissimopoulos and Karoly, 2007; and Pengcharoen and Shultz, 2010) details the types of jobs older workers transition into and what factors influence the choice of transitioning into retirement using bridge jobs. 
The second and mostly newer area of research, focuses on the re-employment trends of those who have retired. ${ }^{1}$ A series of sociology oriented papers suggest a large number of determinants correlated with the re-entry into work by retirees. Hazard models reported in Hayward et al. (1994) suggest that re-entry typically happens only a year or two after initial retirement with professionals being more likely to re-enter full-time employment, while the self-employed and farm workers are more likely to re-enter in part-time employment after retirement. Using more recent data from the Health and Retirement Study Warner et al. (2010) offer generally descriptive evidence that about one-third of retirees re-enter the labour force after retirement in the US, although there is little examination of factors correlating these those transitions. Pleau (2010) finds important differences between re-entry patterns between men and women (with women more affected by 'push factors' correlated with worse socio-economic characteristics), while Pleau and Shauman (2012) look between subsequent waves of Current Population Survey data from 1977 to 2009 to track the incidence of re-entry into work by the retired and find that macroeconomic factors are important in explaining reentry trends over time. Finally, Kail and Warner (2013) estimate age adjusted hazard models that show that re-entry occurs more frequently and lasts longer than earlier research has suggested.

On the other hand, economists have focused less on trends and more on the covariates of reemployment. In an early paper, Honig and Reimers (1987) examine transitions back to work of the retired, indicating that it is more likely for the retired to obtain part time work, rather than full time at low wages. Using HRS data, Cahill et al. (2010) suggest that about fifteen percent of the retired re-enter the labour market, particularly if they were relatively young, in

\footnotetext{
${ }^{1}$ Although not much research has been completed on this, the importance of retaining older individuals in the labour force has been the subject of several papers including concerns about 'labour shortages' (Freeman 2007), the intrinsic value of work for some people (Clark and Fawaz, 2009), and the desire by workers for partial retirement jobs (Hermes, 2007).
} 
good health, and possessing a defined contribution pension. Tatsiramos (2010) examines reemployment from job displacements for older workers in Europe to find that the relative generosity of unemployment insurance and public pensions plays a large role in the reemployment/retirement decision. Garcia-Gomez et al. (2010) find that health plays a key role as well. Maestas (2010) focuses on whether 'unretirement' was expected or not and finds that it is expected by many who retire and then re-enter the labour market.

\section{DATA}

The data used in this project is from the Health and Retirement Study (HRS), a nationally representative survey of the 51 to 61 year old population in 1992. After 1992, respondents are re-interviewed every other year and thus we are able to track individuals for nine waves (sixteen years) in 1992, 1994, 1996, 1998, 2000, 2002, 2004, 2006 and 2008. Given the age range of the sample, most had not retired when they were first sampled in 1992. However, sixteen years later, the vast majority of the sample have already retired at least once (since the youngest are 66 years old in 2008). ${ }^{2}$

This dataset has a wealth of information on individuals. Central to our study is the identification of retirement. While the concept is a simple one, it is difficult to define it in practice. Several definitions are possible (and have been used in the literature). One possibility is to identify those in a 'career job' - typically defined as one where tenure is over some minimum level (e.g. ten years) and follow them until they change out of their career job (either into another job or out of the labour force). Another possibility is to use 'selfreported' retirement information on retirement, asking individuals whether they are retired or not, regardless if they are actually working or not. A third method is to use a strict definition

\footnotetext{
${ }^{2}$ In this paper, we utilize Version J (March 2010) of the HRS data produced by RAND, which is funded by the US National Institute on Aging and the US Social Security Administration.
} 
of retirement where people are retired if they are out of the labour force and are not retired if they are working or looking for work (unemployed). In this paper, we focus on the selfreported retirement definition of retirement, since the definition of out of the labour force can be too strict and the definition of a career job may lead to a possibly arbitrary definition of retirement status. Table 1 below shows the transitions from employment to retirement and back, for each wave of data between 1992 and 2008. While the vast majority of those who are retired in wave $t-1$ remain retired in wave $t$, there is a nontrivial number who are not retired in wave $t$, particularly in the early waves when the respondents are relatively young.

Table 1: Transitions between self-reported retirement status by wave

\begin{tabular}{|c|c|c|c|c|c|c|c|}
\hline & & \multicolumn{6}{|c|}{ Retirement Status at $t$} \\
\hline & & \multicolumn{3}{|c|}{ Cases } & \multicolumn{3}{|c|}{ Percentage } \\
\hline & & Not retired & Retired & Total & Not retired & Retired & Total \\
\hline Wave & Status at $t-1$ & & & & & & \\
\hline \multirow[t]{3}{*}{2} & Not retired & 4,771 & 837 & 5,608 & $85.1 \%$ & $14.9 \%$ & $100.0 \%$ \\
\hline & Retired & 156 & 1,225 & 1,381 & $11.3 \%$ & $88.7 \%$ & $100.0 \%$ \\
\hline & Total & 4,927 & 2,062 & 6,989 & $70.5 \%$ & $29.5 \%$ & $100.0 \%$ \\
\hline \multirow[t]{3}{*}{3} & Not retired & 3,736 & 1,023 & 4,759 & $78.5 \%$ & $21.5 \%$ & $100.0 \%$ \\
\hline & Retired & 209 & 1,696 & 1,905 & $11.0 \%$ & $89.0 \%$ & $100.0 \%$ \\
\hline & Total & 3,945 & 2,719 & 6,664 & $59.2 \%$ & $40.8 \%$ & $100.0 \%$ \\
\hline \multirow[t]{3}{*}{4} & Not retired & 2,888 & 890 & 3,778 & $76.4 \%$ & $23.6 \%$ & $100.0 \%$ \\
\hline & Retired & 198 & 2,053 & 2,251 & $8.8 \%$ & $91.2 \%$ & $100.0 \%$ \\
\hline & Total & 3,086 & 2,943 & 6,029 & $51.2 \%$ & $48.8 \%$ & $100.0 \%$ \\
\hline \multirow[t]{3}{*}{5} & Not retired & 2,130 & 911 & 3,041 & $70.0 \%$ & $30.0 \%$ & $100.0 \%$ \\
\hline & Retired & 194 & 2,518 & 2,712 & $7.2 \%$ & $92.8 \%$ & $100.0 \%$ \\
\hline & Total & 2,324 & 3,429 & 5,753 & $40.4 \%$ & $59.6 \%$ & $100.0 \%$ \\
\hline \multirow[t]{3}{*}{6} & Not retired & 1,479 & 882 & 2,361 & $62.6 \%$ & $37.4 \%$ & $100.0 \%$ \\
\hline & Retired & 184 & 2,941 & 3,125 & $5.9 \%$ & $94.1 \%$ & $100.0 \%$ \\
\hline & Total & 1,663 & 3,823 & 5,486 & $30.3 \%$ & $69.7 \%$ & $100.0 \%$ \\
\hline \multirow[t]{3}{*}{7} & Not retired & 1,029 & 755 & 1,784 & $57.7 \%$ & $42.3 \%$ & $100.0 \%$ \\
\hline & Retired & 167 & 3,782 & 3,949 & $4.2 \%$ & $95.8 \%$ & $100.0 \%$ \\
\hline & Total & 1,196 & 4,537 & 5,733 & $20.9 \%$ & $79.1 \%$ & $100.0 \%$ \\
\hline \multirow[t]{3}{*}{8} & Not retired & 703 & 560 & 1,263 & $55.7 \%$ & $44.3 \%$ & $100.0 \%$ \\
\hline & Retired & 142 & 4,134 & 4,276 & $3.3 \%$ & $96.7 \%$ & $100.0 \%$ \\
\hline & Total & 845 & 4,694 & 5,539 & $15.3 \%$ & $84.7 \%$ & $100.0 \%$ \\
\hline \multirow[t]{3}{*}{9} & Not retired & 503 & 442 & 945 & $53.2 \%$ & $46.8 \%$ & $100.0 \%$ \\
\hline & Retired & 143 & 4,209 & 4,352 & $3.3 \%$ & $96.7 \%$ & $100.0 \%$ \\
\hline & Total & 646 & 4,651 & 5,297 & $12.2 \%$ & $87.8 \%$ & $100.0 \%$ \\
\hline
\end{tabular}


The covariates used in the study are standard ones that are assumed to affect the retirement decision. In addition to the common demographic variables (gender, race, age, and education), we include a measure for marital status and whether the spouse is working or retired, since previous research has shown that joint decision making in retirement is important. We also include measures of health, since poor health can affect the ability to work particularly at these ages. Descriptive statistics are presented in Table 2 below.

We utilise a variety of economic measures such as household income (to identify any substitution effects), and housing and financial wealth (to identify income effects) on retirement. The wealth and income variables are presented in the form of three quartile variables to reflect possible non-linear effects.

Table 2: Means and standard deviations of variables

\begin{tabular}{llc}
\hline Variable & Mean & Standard deviation \\
\hline Retired at t & 0.549 & 0.498 \\
Age 62 to 64 & 0.165 & 0.371 \\
Age 65 plus & 0.381 & 0.486 \\
Female & 0.520 & 0.500 \\
College & 0.194 & 0.396 \\
Spouse working & 0.268 & 0.443 \\
Spouse retired & 0.304 & 0.460 \\
Health (work limiting) & 0.239 & 0.426 \\
No health insurance & 0.123 & 0.328 \\
Net housing wealth 25 to $50 \%$ & 0.253 & 0.435 \\
Net housing wealth 50 to $75 \%$ & 0.248 & 0.432 \\
Net housing wealth 75 to $100 \%$ & 0.247 & 0.432 \\
Net financial wealth 25 to $50 \%$ & 0.251 & 0.434 \\
Net financial wealth 50 to $75 \%$ & 0.250 & 0.433 \\
Net financial wealth 75 to $100 \%$ & 0.249 & 0.432 \\
Household income per head 25 to $50 \%$ & 0.245 & 0.430 \\
Household income per head 50 to $75 \%$ & 0.250 & 0.433 \\
Household income per head 75 to $100 \%$ & 0.250 & 0.433 \\
\hline Note: Pooled data from HRS waves $1-9(1992-2008)$. Sample size $=56913$. Household income per head refers to the year \\
prior to interview, for example, the income recorded at the 1992 interview, refers to paid employment income earned in the \\
year 1991.
\end{tabular}




\section{METHOD}

Unlike the literature above, the paper utilises the panel nature of the HRS data to control for individual heterogeneity. The basic estimating equation is:

$$
R E T_{i t}=X_{i t}^{\prime} \beta+\gamma R E T_{i t-1}+\varepsilon_{i}+u_{i t}
$$

for $i=1, \ldots, N$, individuals observed over $t=2, \ldots, T$ periods. $R E T_{i t}$ is the reported retirement indicator variable which takes the value 1 for those who consider themselves to be retired and 0 for those who consider themselves to be in employment at $t, X_{i t}$ contains all observed explanatory variables and $\varepsilon_{i}$ and $u_{i t}$ are components of the error term with $u_{i t}$ assumed to be iid. To estimate Equation 1 we use a dynamic random effects probit estimation method, along the lines assumed by Stewart (2007). Two subtle but nonetheless serious estimation problems would arise if Equation 1 were to be estimated using a standard random effects framework.

The first problem would result from the oft criticised as unrealistic assumption of zero correlation between the error terms and the covariates in the random effects model. This can be resolved using Mundlak (1978) corrections. This is done by assuming that the relationship between $X_{i t}$ and $\varepsilon_{i}$ can be written as $\varepsilon_{i}=\bar{X}_{i}^{\prime} \alpha+v_{i}$, where $v_{i} \sim$ iid follows the normal distribution and is independent of $X_{i t}$ and $u_{i t}$ for all $i$ and $t$. In practice Mundlak corrections can be applied by including in the right-hand side of Equation 1 the individual (over time) means for each of the time-varying explanatory variables.

The second problem arises from the possibility that the lagged dependent variable in the right-hand side of Equation 1 may be correlated with the error terms. To the degree that the individual specific error term $\varepsilon_{i}$ may be time-invariant, it is possible that even after we have corrected for the potential correlation of the individual specific error term with observed contemporaneous factors (the $X_{i t}$ ), $\varepsilon_{i}$ may still be a source of bias by being correlated with the 
lagged dependent variable. It can be shown that assuming that $R E T_{i t-1}$ and $\varepsilon_{i}$ are uncorrelated amounts to assuming that the first observation of $R E T_{i 1}$ is uncorrelated with the individualspecific error term $\varepsilon_{i}$. This assumption is difficult to justify on empirical or theoretical grounds. The problem was first examined in detail in the econometrics literature by Heckman (1981), and it has been named the problem of initial conditions. Ignoring initial conditions that are correlated with the individual-specific error term $\varepsilon_{i}$ results in overestimating state dependence. In practical terms, this will result in an overstated coefficient of $R E T_{i t-1}$ in Equation 1. Heckman (1981) proposes that initial conditions be modelled by using the values of the first wave of a panel dataset to approximate the true values of the initial conditions.

Alternative estimators to the one developed by Heckman have been proposed by Orme (2001) and Wooldridge (2005). This paper follows the method of Wooldridge (2005) and combines it with the Mundlak (1978) method to estimate the following equation ${ }^{3}$ :

$$
R E T_{i t}=X_{i t}^{\prime} \beta+\delta R E T_{i 1}+\gamma R E T_{i t-1}+\bar{X}_{i}^{\prime} \alpha+v_{i}+u_{i t}
$$

We estimate a number of variants of Equation 2, focusing on including in the first instance the $2^{\text {nd }}$ and $3^{\text {rd }}$ lags of the dependent variable. The lagged dependent variables will indicate the degree to which there is any retirement state persistence (for those who chose to retire) and how long this persistence may last.

In addition to the standard demographic characteristics in the $X$ vectors, we focus on the three different financial and income variables: Housing Wealth, Financial Wealth and Per Person Household Income. The two wealth variables will reflect the income effect of retirement

\footnotetext{
${ }^{3}$ Arulampalam and Stewart (2009) compare a convenient shortcut for implementing the Heckman method with the Orme and the Wooldridge estimators to conclude that "it is advantageous to allow for correlated random effects using the approach of Mundlak (1978), but once this is done, the three estimators provide similar results" (p. 679). In this paper we assume the Wooldridge estimator for mere computational speed and convenience, with the implementation of the full two stage Heckman method planned as the next estimation step.
} 
decisions, that is their estimates will suggest if retirement is considered to be a positively valued leisure good, in which case we would expect that the richer people will be able to "buy" more of it, that is, they will be more likely to retire. The expected estimated sign for the wealth variables will therefore be positive.

There is one main difference between the two wealth variables, which may be age-related. Housing wealth will typically be far less liquid that the financial assets wealth. This would imply that the level of housing wealth may not be as important in any short-run changes in the retirement status, at least among those who have repaid their mortgage in full. By contrast, wealth represented by other financial assets will be more flexible in the short-run and can be expected to have a more immediate influence on retirement plans.

A potential complication in the wealth variable is endogeneity. As we outline above, the expected direction of causation is that increases as an income effect on leisure and increases the probability of retirement. However, common sense suggests that expectations about retirement can affect wealth accumulation. For example, a person who wants to retire 'early' may save significantly more during their working life, leading to increased wealth. However, there are reasons to think that this endogeneity will be less pronounced due to the part of the life cycle that these individuals are in. Cagetti (2003), using data from the Panel Study of Income Dynamics and the Survey of Consumer finances, finds that early savings and wealth accumulation is due primarily to a desire for precautionary savings and while that desire eventually changes to savings for retirement, the rate of growth in wealth accumulation slows considerably by the time individuals reach the age of 60 (see, in particular, Figures 1 and 2, pp. 342-3). Thus by the time our panel starts (between ages 51-61 in 1992), the vast majority of wealth accumulation has already occurred, leaving the main direction of causation from 
wealth to retirement. In addition, any heterogeneity that may be left will be, in part, mitigated by estimating an individual effect in equation $2\left(v_{i}\right)$.

Unlike the wealth variables, the income in paid employment variable will represent the substitution effect on retirement decisions. Someone with a higher earned income will have a lower propensity to retire as buying more leisure will cost them more than it would cost someone with a lower earned income. That is, workers with higher earned income have a higher shadow cost to their time and will therefore stay in employment. The expected estimated sign for the earned income variable will therefore be negative.

The second variant of Equation 2 uses only the first lag of the dependent variable as an estimate of state persistence and interacts it with the wealth and income variables to examine if the effect of state persistence is carried through to the income and substitution of leisure effects. There are no clear theoretical priors for these interaction terms.

\section{ESTIMATION RESULTS AND DisCUSSION}

Table 3 presents three variants of Equation 2, Model 1 with only one lag, Model 2 with two and Model 3 with three lags. ${ }^{4}$ All three lags are statistically significant. The first lag which is the most important one suggests strong state persistence. ${ }^{5}$ As age advances, the probability to retire increases. Males appear to be more likely to retire, but the small difference could be the result of conditioning differences in employment status at a younger age.

\footnotetext{
${ }^{4}$ In Appendix Table A1, we present a random effects probit model with the same variable specification, but without the dynamics of the lagged retirement variable. Looking across many of the coefficients, we can see that there are some substantial movement in some, indicating the importance of including the dynamics as in Table 3.

${ }^{5}$ Here and below in Table 4, we present just the estimated coefficients of the model, rather than the marginal effects. This is done because the calculation of the marginal effects for interacted coefficients in Table 4 is much more complex than in the noninteracted case. Thus we focus on the coefficients to give us a sense of the direction of the effect and whether that direction is significantly different from zero.
} 
Table 3: Dynamic RE Probit Estimations of Self-reported Retirement (Coefficient Estimates)

\begin{tabular}{|c|c|c|c|c|c|c|}
\hline \multirow{3}{*}{ Main estimation results } & \multicolumn{2}{|c|}{ Model 1} & \multicolumn{2}{|c|}{ Model 2} & \multicolumn{2}{|c|}{ Model 3} \\
\hline & \multirow[t]{2}{*}{ Coef } & \multirow[t]{2}{*}{ (z value) } & \multicolumn{2}{|c|}{ Coef (z value) } & \multirow[t]{2}{*}{ Coef } & \multirow[t]{2}{*}{ (z value) } \\
\hline & & & & & & \\
\hline Retired at t-1 & 1.402 & $(53.10)$ & 1.377 & $(52.06)$ & 1.402 & $(48.50)$ \\
\hline Retired at t-2 & - & - & 0.468 & (15.33) & 0.467 & (15.89) \\
\hline Retired at t-3 & - & - & - & - & 0.199 & $(5.21)$ \\
\hline Age 62 to 64 & 0.936 & (33.11) & 0.820 & $(26.44)$ & 0.763 & (20.30) \\
\hline Age 65 plus & 1.377 & $(37.44)$ & 1.110 & $(27.50)$ & 0.986 & (21.63) \\
\hline Female & -0.160 & $(-6.82)$ & -0.141 & $(-6.00)$ & -0.129 & $(-5.04)$ \\
\hline College & 0.013 & $(0.41)$ & -0.002 & $(-0.07)$ & 0.026 & $(0.80)$ \\
\hline Spouse working & -0.280 & $(-7.31)$ & -0.206 & $(-4.59)$ & -0.179 & $(-3.30)$ \\
\hline Spouse retired & 0.190 & $(5.45)$ & 0.180 & $(4.57)$ & 0.142 & (3.09) \\
\hline Health problem (work limiting) & 0.723 & $(21.41)$ & 0.624 & $(16.33)$ & 0.602 & $(13.40)$ \\
\hline No health insurance & 0.268 & $(7.46)$ & 0.285 & (6.89) & 0.265 & $(5.15)$ \\
\hline Net housing wealth 25 to $50 \%$ & 0.001 & $(0.03)$ & 0.022 & $(0.50)$ & 0.089 & $(1.67)$ \\
\hline Net housing wealth 50 to $75 \%$ & 0.043 & $(1.01)$ & 0.007 & $(0.14)$ & 0.031 & $(0.54)$ \\
\hline Net housing wealth 75 to $100 \%$ & 0.135 & $(2.79)$ & 0.068 & $(1.25)$ & 0.087 & $(1.39)$ \\
\hline Net financial wealth 25 to $50 \%$ & 0.079 & $(2.49)$ & 0.109 & (3.07) & 0.066 & $(1.61)$ \\
\hline Net financial wealth 50 to $75 \%$ & 0.173 & $(4.61)$ & 0.184 & $(4.41)$ & 0.195 & $(4.01)$ \\
\hline Net financial wealth 75 to $100 \%$ & 0.328 & $(7.41)$ & 0.335 & $(6.84)$ & 0.383 & $(6.76)$ \\
\hline Household income per head 25 to $50 \%$ & -0.242 & $(-7.02)$ & -0.269 & $(-6.75)$ & -0.280 & $(-5.89)$ \\
\hline Household income per head 50 to $75 \%$ & -0.412 & $(-10.77)$ & -0.424 & $(-9.63)$ & -0.442 & $(-8.49)$ \\
\hline Household income per head 75 to $100 \%$ & -0.561 & $(-13.21)$ & -0.584 & $(-12.10)$ & -0.639 & $(-11.27)$ \\
\hline \multicolumn{7}{|l|}{ Mundlak corrections } \\
\hline Age 62 to 64 & 0.006 & $(0.08)$ & -0.033 & $(-0.39)$ & -0.128 & $(-1.31)$ \\
\hline Age above 64 & -0.098 & $(-1.79)$ & -0.104 & $(-1.86)$ & -0.184 & $(-2.73)$ \\
\hline Spouse working & 0.013 & $(0.24)$ & -0.009 & $(-0.15)$ & -0.023 & $(-0.34)$ \\
\hline Spouse retired & 0.284 & $(5.66)$ & 0.219 & $(4.20)$ & 0.210 & $(3.60)$ \\
\hline Health problem (work limiting) & 0.339 & $(6.74)$ & 0.223 & (4.19) & 0.151 & $(2.52)$ \\
\hline No health insurance & -0.547 & $(-8.27)$ & -0.537 & $(-7.32)$ & -0.529 & $(-5.87)$ \\
\hline Net housing wealth 25 to $50 \%$ & 0.134 & $(2.25)$ & 0.078 & $(1.22)$ & -0.002 & $(-0.03)$ \\
\hline Net housing wealth 50 to $75 \%$ & 0.077 & $(1.22)$ & 0.134 & $(2.00)$ & 0.077 & $(1.02)$ \\
\hline Net housing wealth 75 to $100 \%$ & 0.035 & $(0.51)$ & 0.097 & $(1.36)$ & 0.078 & $(0.97)$ \\
\hline Net financial wealth 25 to $50 \%$ & 0.068 & $(1.06)$ & 0.004 & $(0.05)$ & 0.099 & $(1.38)$ \\
\hline Net financial wealth 50 to $75 \%$ & 0.182 & $(2.79)$ & 0.126 & $(1.87)$ & 0.088 & (1.19) \\
\hline Net financial wealth 75 to $100 \%$ & 0.348 & $(4.82)$ & 0.243 & $(3.29)$ & 0.179 & $(2.19)$ \\
\hline Household income per head 25 to $50 \%$ & -0.008 & $(-0.12)$ & 0.060 & $(0.89)$ & 0.064 & $(0.84)$ \\
\hline Household income per head 50 to $75 \%$ & 0.079 & $(1.21)$ & 0.087 & $(1.28)$ & 0.085 & $(1.11)$ \\
\hline Household income per head 75 to $100 \%$ & -0.204 & $(-2.96)$ & -0.136 & $(-1.90)$ & -0.121 & $(-1.50)$ \\
\hline Sample size (persons) & \multicolumn{2}{|c|}{$44670(8606)$} & \multicolumn{2}{|c|}{36173 (7803) } & \multicolumn{2}{|c|}{28654 (7023) } \\
\hline Log likelihood & \multicolumn{2}{|c|}{-15150.651} & \multicolumn{2}{|c|}{-11935.784} & \multicolumn{2}{|c|}{-9072.8773} \\
\hline
\end{tabular}


Being a college graduate does not appear to make a difference in itself, presumably because by that stage the full effect of college will have been translated into wealth and income with little residual or option labour market value to the individual. Note that the female and college are time invariant variables that belong to the Mundlak corrections list.

Having a working spouse reduces the probability of retirement and having a retired spouse increases it (with single individuals the reference group), indicating that the retirement decision is made jointly among couples. Finally, having a work limiting health problem increases the probability of retirement. Those without health insurance are more likely to retire. Although it is not clear why this may be so, it may be for workers without health insurance retiring so that they can avail themselves of public forms of health insurance such as Medicare or Medicaid.

Both wealth and income variables confirm conventional human capital theoretical predictions with a positive income effect and a negative substitution effect in place. Housing wealth always has a positive effect on the probability to retire but appears to matter only a little and only for those whose housing wealth belongs to the top $25 \%$ in the country. The inclusion of the second and third retirement lags in Models 2 and 3 appears to reduce the statistical significance of the one housing wealth variable that is significant in Model $1 .^{6}$ Net financial wealth is far more influential when it comes to the retirement decision. A clear positive income effect is estimated and remains significant after the inclusion of all three lags in Model 3. Furthermore, other things equal, people whose financial assets belong to the top $25 \%$ category of people aged above 51 , are considerably more likely to transit into retirement

\footnotetext{
${ }^{6}$ This is likely the result of the different sample in the third lagged model which is considerably smaller since we have to drop out two additional waves of the HRS (the first wave is dropped when we have the first lag). As can be seen in Appendix Table A2, which holds the sample constant at the one where there are three lags indicates that this variable is only significant at the 10 percent level for this sample.
} 
and considerably more likely to be in retirement than their counterparts at the lowest $25 \%$ financial assets category.

The effect of household income per head on retirement transitions is unambiguously negative, in support of the theoretical prediction of a negative substitution effect. This substitution effect is both strong and, unlike the (income) effect of wealth, it begins to be present from the second quartile peaking almost linearly in the fourth quartile.

Having established that there is considerable state persistence in retirement transitions and that there is a significant positive income effect and a significant negative substitution effect, we move to Table 4 which estimates Equation 2 with the dependent variable lagged only once and interacts this lagged variable with all wealth and income variables to examine if state persistence accentuates or ameliorates the estimated income and substitution effects. The intuition behind this estimation is to see if the effect of wealth and income on the decision to retire may also influence the later decision(s) to remain retired or not, in the sense of reinforcing the continuation of retirement or not, over and above all the other factors that led to the retirement decision in the first place. To test this we generated nine new interaction variables.

There are two main observations that arise from Table 4. To begin with, results remain largely unaffected by the inclusion of the interaction variables. This is a welcome result regarding the robustness of the specification of the model. Importantly, the lagged dependent variable and the wealth and income variables are almost unaffected by the inclusion of the interaction terms. 


\section{Coefficient $\mathrm{Z}$ value}

\section{Main effects}

Retired at $\mathrm{t}-1$

$1.196 \quad 21.72$

Age 62 to 64

$0.931 \quad 32.96$

Age above 64

$1.366 \quad 37.12$

Female

$-0.159$

$-6.84$

College

0.013

0.41

Spouse working

$-0.278 \quad-7.26$

Spouse retired

0.187

5.37

Health (work limiting)

0.721

21.43

No health insurance

0.255

7.12

Net housing wealth 25 to $50 \%$

$0.000 \quad-0.01$

Net housing wealth 50 to $75 \%$

0.048

Net housing wealth 75 to $100 \%$

0.132

2.51

Net financial wealth 25 to $50 \%$

$0.054 \quad 1.48$

Net financial wealth 50 to $75 \%$

$0.148 \quad 3.54$

Net financial wealth 75 to $100 \%$

$0.272 \quad 5.57$

Household income per head 25 to $50 \%$

$-0.283 \quad-7.25$

Household income per head 50 to $75 \%$

$-0.481 \quad-11.39$

Household income per head 75 to $100 \%$

$-0.608 \quad-13.14$

Interaction of financial terms with Retired at $\mathrm{t}-1$

Net housing wealth 25 to $50 \%$

\begin{tabular}{cc}
0.008 & 0.14 \\
-0.019 & -0.32 \\
-0.017 & -0.26 \\
0.070 & 1.23 \\
0.072 & 1.18 \\
0.170 & 2.54 \\
0.137 & 2.35 \\
0.240 & 3.92 \\
0.174 & 2.72 \\
\multicolumn{2}{c}{$44670(8606)$} \\
-15133.21
\end{tabular}

Net housing wealth 50 to $75 \%$

Net housing wealth 75 to $100 \%$

Net financial wealth 25 to $50 \%$

Net financial wealth 50 to $75 \%$

Household income per head 25 to $50 \%$

Household income per head 50 to $75 \%$

Household income per head 75 to $100 \%$

$$
-15133.21
$$

Log likelihood

Notes: Omitted reference groups are less than age 62, male, without college education, not married, without work limiting health problem, with health insurance, net housing wealth 0-25\%, net financial wealth $0-25 \%$ and household income per head 0 to 25\%; Mundlak corrections were included in the regression but estimates are not presented here. 
Focusing on the interaction terms, they appear to be containing some valuable additional information and intuition about the relationship between the retirement decision and wealth and income. The interaction between housing wealth reinforces the previous message, namely, that the level of housing wealth does not seem to affect retirement decisions. Not even those with the highest level of housing wealth find their state persistence interact with their wealth. The interaction with financial assets shows a weak positive result only for those in the highest financial assets quartile. So, overall, the income effect of wealth does not appear to be reinforcing state persistence in any empirically noteworthy way.

By contrast, the interaction between household income and the retirement decision produces a clearly signed and statistically significant result. Whilst earning a higher income appears to be making the decision to transit to retirement less likely, at the same time it appears to be making the persistence of that decision lower (that is making the probability of future retirement higher).

This is a highly intuitive result with interesting policy implications. For example, policies that may provide tax exemptions in order to attract mature age workers to stay in the labour force will probably be more short-lived than the initial increase in labour supply may suggest. Policies that try to work through the increase in pension savings (included in the financial assets) will reduce labour supply in the long run.

\section{CONCLUSION}

This paper has estimated the propensity to retire and the persistence of remaining retired once the decision to retire has been made. The paper focused on the estimation of the level of persistence and found it to be considerable. It also focussed on the effect of the level of 
different financial assets on the decision to retire. Results suggest that the level of housing wealth is of virtually no consequence regarding the decision to retire. By contrast, wealth in the form of financial assets, clearly encourages the decision to retire, but the effect does not appear to be large. Results on household income from paid employment in the year preceding retirement suggest clearly that the opportunity to earn a high income reduces the probability to retire. These results show a clear but weak income effect and a clear and strong substitution effect as human capital theory would predict. The paper goes on to examine the degree to which the estimated state persistence of retirement is reinforced or not by financial and housing wealth and by earned income. Results suggest that wealth has virtually no effect on the persistence of the retirement decision. Results also suggest that, while higher earned income may make retirement less likely in the first instance, it may make retirement more persistent when it happens in the future. 


\section{REFERENCES}

Anderson, K. H., R. V. Burkhauser and J. F. Quinn. 1986. "Do Retirement Dreams Come True? The Effects of Unanticipated Events on Retirement Plans," Industrial and Labor Relations Review, 39: 518-26.

Arulampalam, W. and M. B. Stewart. 2009. "Simplified Implementation of the Heckman Estimator of the Dynamic Probit Model and a Comparison with Alternative Estimators” Oxford Bulletin of Economics and Statistics, 71(5): 659-81.

Boskin, M. J. and M. D. Hurd. 1978. "The Effect of Social Security on Early Retirement," Journal of Public Economics, 10: 361-77.

Bowen, W. and T. Finigan. 1969. The Economics of Labour Force Participation, Princeton, NJ: Princeton University Press.

Burkhauser, R.V. 1979. “The Pension Acceptance Decision of Older Workers,” Journal of Human Resources, 14: 63-75.

Burkhauser, R.V. 1980. "The Early Acceptance of Social Security An Asset Maximisation Approach,” Industrial and Labour Relations Review, 33: 484-92.

Burtless, G. 1986. "Social Security, Unanticipated Benefit Increases and Timing of Retirement” Review of Economic Studies, 53, 781-805.

Cagetti, M. 2003. "Wealth Accumulation Over the Life Cycle and Precautionary Savings," Journal of Business \& Economic Statistics, 21(3): 339-53.

Cahill, K., M. Giandrea and J. F. Quinn. 2005. "Are Traditional Retirements a Thing of the Past? New Evidence on Retirement Patterns and Bridge Jobs,” Boston College Working Papers in Economics, 626.

Cahill, K. E., M. D. Giandrea and J. F. Quinn. 2010. "The Role of Re-entry in the Retirement Process,” BLS Working Paper 439, US Bureau of Labor Statistics.

Clark, A. E. and Y. Fawaz. 2009. "Valuing Jobs via Retirement: European Evidence," National Institute Economic Review, 209: 88-103.

Coile, C. C. and P. B. Levine. 2006. “Bulls, Bears, and Retirement Behavior,” Industrial and Labor Relations Review, 59(3): 408-29.

Crawford, V. P. and M. D. Lilien. 1981. "Social Security and the Retirement Decision," Quarterly Journal of Economics, 96: 505-29.

Diamond, P. A. and J. A. Hausman. 1984. "The Retirement and Unemployment Behaviour of Older Men" in H. Aaron and G. Burtless (eds), Retirement and Economic Behaviour, Washington DC: Brookings Institution. 
Feldstein, M. 1974. "Social Security, Induced Retirement, and Aggregate Capital Accumulation,” Journal of Political Economy, 82: 905-26.

Fields, G. and O. S. Mitchell. 1984a. "Economic Determinants of the Optimal Retirement Age: An Empirical Investigation,” Journal of Human Resources, 19: 245-262.

Fields, G. and O. S. Mitchell. 1984b. "The Effects of Social Security Reforms on Retirement Ages and Retirement Incomes,” Journal of Public Economics, 25: 143-59.

Filer, R. K. and P.A. Petri. 1988. “A Job Characteristics Theory of Retirement,” Review of Economics and Statistics, 70: 123-29.

Freeman, R. B. 2007. "Is a Great Labor Shortage Coming? Replacement Demand in the Global Economy." in Reshaping the American Workforce in a Changing Economy, H. J. Holzer and D. S. Nightingale (eds.), Urban Institute Press: Washington DC, pp. 3-23.

French, E. 2005. "The Effects of Health, Wealth, and Wages on Labor Supply and Retirement Behavior,” Review of Economic Studies, 72(2): 395-427.

Fronstin, P. 1999. "Retirement Patterns and Employee Benefits: Do Benefits Matter?” The Gerontologist, 39(1): 37-47.

Garcia-Gomez, P., A. M. Jones, and N. Rice. 2010. "Health Effects on Labour Market Exits and Entries,” Labour Economics, 17(1): 62-76.

Gordon, R. H. and A.S. Blinder. 1980. "Market Wages, Reservation Wages, and Retirement Decisions,” Journal of Public Economics, 14: 277-308.

Gustman, A., O. Mitchell, and T. Steinmeier. 1994. "The Role of Pensions in the Labor Market: A Survey of the Literature,” Industrial and Labor Relations Review, 47(3): 417-38.

Gustman, A. and T. Steinmeier. 1984. "Partial Retirement and the Analysis of Retirement Behavior," Industrial and Labor Relations Review, 37(3): 403-15.

Gustman, A. and T. Steinmeier. 1986. “A Structural Retirement Model,” Econometrica, 54(3): 555-84.

Gustman, A. and T. Steinmeier. 2000. "Retirement in Dual-Career Families: A Structural Model,” Journal of Labor Economics, 18(3): 503-45.

Hanel, B. 2010. "Financial Incentives to Postpone Retirement and Further Effects on Employment - Evidence from a Natural Experiment," Labour Economics, 17(3): 47486.

Hausman, J. A. and D. A. Wise. 1985. "Social Security, Health Status, and Retirement," in Pensions, Labor and Individual Choice. D. A. Wise (ed.). Chicago: University of Chicago Press. 
Hayward, M. D., M. A. Hardy and M. C. Liu. 1994. "Work after Retirement: The Experiences of Older Men in the United States," Social Science Research, 23: 82-107.

Heckman, J. J. 1981. "The Incidental Parameters Problem and the Problem of Initial Conditions in Estimating a Discrete time-Discrete Data Stochastic Process,” in Structural Analysis of Discrete Data with Econometric Applications. CF Manski and D. McFadden (eds.) Cambridge MA: MIT Press, pp. 114-78.

Hermes, S. 2007. "Partial Retirement: Widespread Desire among Workers, but Limited Demand by Employers," in Employee Pensions: Policies, Problems, and Possibilities ed. by T. Ghilarducci and C.E. Weller, Labor and Employment Relations Association: Champaign, IL, pp. 69-83.

Heyma, A. 2004. "A Structural Dynamic Analysis of Retirement Behaviour in the Netherlands,” Journal of Applied Econometrics, 19: 739-59.

Honig, M. and C. Reimers. 1987. "Retirement, Re-entry, and Part-time Work," Eastern Economic Journal, 13(4): 361-71.

Kail, B. L. and D. F. Warner. 2013. "Leaving Retirement: Age-Graded Relative Risks of Transitioning Back to Work or Dying,” Population Research and Policy Review: 32: 159-82.

Kapur, K. and J. Rogowski. 2007. "The Role of Health Insurance in Joint Retirement among Married Couples,” Industrial and Labor Relations Review, 60(3): 397-407.

Lumsdaine, R. L., J. H. Stock, and D. A. Wise. 1997. "Retirement Incentives: The Interaction between Employer-Provided Pensions, Social Security, and Retiree Health Benefits," in The Economic Effects of Aging in the United States and Japan. M. D. Hurd and N. Yashiro (eds). Chicago: University of Chicago Press, pp. 261-292.

Maestas, N. 2010. "Back to Work: Expectations and Realizations of Work after Retirement," Journal of Human Resources, 45(3): 718-48.

Mitchell, O. S. and G. S. Fields. 1984. “The Economics of Retirement Behavior,” Journal of Labor Economics, 2(1): 84-105.

Mundlak, Y. 1978. “On the Pooling of Time Series and Cross Section Data,” Econometrica, 46: 69-85.

Orme, C. 2001. “Two-Step inference in Dynamic Non-Linear Panel Data Models.” mimeo, University of Manchester.

Parsons, D. 1980. "The Decline of Labour Force Participation," Journal of Political Economy, 88: 117-134.

Pengcharoen, C. and K. S. Shultz. 2010. "The Influences on Bridge Employment Decisions,” International Journal of Manpower, 31(3): 322-36. 
Pleau, R. L. 2010. “Gender Differences in Postretirement Employment,” Research on Aging, 32(3): 267-303.

Pleau, R. and K. Shauman. 2012. "Trends and Correlates of Post-retirement Employment, 1977-2009,” Human Relations, 66(1): 113-41.

Quinn, J. F. 1977. "Microeconomic Determinants of Early Retirements," in Handbook of Ageing and the Social Sciences, R. H. Binstock and L.K. George (eds.), San Diego: Academic Press.

Quinn, J. F. 1996. “The Role of Bridge Jobs in the Retirement Patterns of Older Americans in the 1990s,” Boston College Working Papers in Economics, 324.

Quinn, J. F. and M. Kozy. 1995. "The Roles of Part-time Work and Self-Employment in the Retirement Transition: A Preliminary View from the HRS,” Boston College Working Papers in Economics, 292.

Quinn, J. F. and R. Burkhauser. 1990. "Work and Retirement," in Handbook of Aging and the Social Sciences, 3d ed., R. H. Binstock and L. K. George (eds.), San Diego: Academic Press, pp. 307-27.

Ruhm, C. 1990. "Bridge Jobs and Partial Retirement,” Journal of Labor Economics, 8(4): 482-501.

Rust, J. 1989. “A Dynamic Programming Model of Retirement Behavior,” in The Economics of Aging, D. A. Wise (ed.), Chicago: University of Chicago Press.

Samwick, A. A. 1998. "New Evidence on Pensions, Social Security, and the Timing of Retirement,” Journal of Public Economics, 70(2): 207-36.

Stewart, M. B. 2007. “The Inter-related Dynamics of Unemployment and Low Pay,” Journal of Applied Econometrics, 22: 511-31.

Sheshinski, E. 1978. “A Model of Social Security and Retirement Decisions,” Journal of Public Economics, 10: 337-60.

Tatsiramos, K. 2010. "Job Displacement and the Transitions to Re-employment and Early Retirement for Non-employed Older Workers,” European Economic Review, 54(4): 517-35.

Vanderhart, M. J. 2003. "Labor Supply of Older Men: Does Social Security Matter?” Economic Inquiry, 41(2): 250-63.

Warner, D. F., M. D. Hayward and M. A. Hardy. 2010. "The Retirement Life Course in America at the Dawn of the Twenty-First Century," Population Research and Policy Review, 29: 893-919.

Woodridge, J. 2005. "Simple Solutions to the Initial Conditions Problem in Dynamic, Nonlinear Panel Data Models with Unobserved Heterogeneity,” Journal of Applied Econometrics, 20: 39-54. 
Zissimopoulos, J. M. and L. A. Karoly. 2007. “Transitions to Self-Employment at Older Ages: The Role of Wealth, Health, Health Insurance, and Other Factors,” Labour Economics, 14(2): 269-95. 


\section{APPENDiX}

\section{Definition of Variables}

Retired(t): (Dependent variable) Self-reported dummy variable: takes the value 1 if an individual is retired, zero otherwise.

Retired(t-1 to t-3): (Independent variables) Self-reported dummy variable: takes the value 1 if an individual is retired, zero otherwise.

Age:

Age 62 to 64: Dummy variable, takes the value 1 if an individual is aged between 60 and 64, zero otherwise.

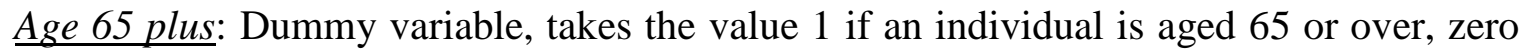
otherwise.

Age 61 minus: reference category.

Female: Dummy variable, takes the value 1 if an individual is female, zero otherwise.

College: Dummy variable, takes the value 1 if an individual has college education, zero otherwise.

\section{Marital status:}

Spouse working: Dummy variable, takes the value 1 if an individual has a spouse working, zero otherwise.

Spouse retired: Dummy variable, takes the value 1 if an individual has a spouse retired, zero otherwise.

Not married: reference category.

Health problem (work limiting): Dummy variable, takes the value 1 if an individual has a work- limited health problem, zero otherwise.

No health insurance: Dummy variable, takes the value 1 if an individual has no health insurance, zero otherwise. 


\section{Net housing wealth:}

Net housing wealth 0 to 25\%: reference category.

Net housing wealth 25 to 50\%: Dummy variable, takes the value 1 if an individual's net housing wealth is in the 25 to $50 \%$ quartile of the sample, zero otherwise.

Net housing wealth 50 to 75\%: Dummy variable, takes the value 1 if an individual's net housing wealth is in the 50 to $75 \%$ quartile of the sample, zero otherwise.

Net housing wealth 75 to 100\%: Dummy variable, takes the value 1 if an individual's net housing wealth is in the 75 to $100 \%$ quartile of the sample, zero otherwise.

\section{Net financial wealth:}

Net financial wealth 0 to 25\%: reference category.

Net financial wealth 25 to 50\%: Dummy variable, takes the value 1 if an individual's net financial wealth is in the 25 to $50 \%$ quartile of the sample, zero otherwise.

Net housing wealth 50 to 75\%: Dummy variable, takes the value 1 if an individual's net financial wealth is in the 50 to $75 \%$ quartile of the sample, zero otherwise.

Net housing wealth 75 to 100\%: Dummy variable, takes the value 1 if an individual's net financial wealth is in the 75 to $100 \%$ quartile of the sample, zero otherwise.

\section{Household income per head:}

Household income per head 0 to 25\%: reference category.

Household income per head 25 to 50\%: Dummy variable, takes the value 1 if an individual's household income per head in the previous year is in the 25 to $50 \%$ quartile of the sample, zero otherwise.

Household income per head 50 to 75\%: Dummy variable, takes the value 1 if an individual's household income per head in the previous year is in the 50 to $75 \%$ quartile of the sample, zero otherwise. 
Household income per head 75 to 100\%: Dummy variable, takes the value 1 if an individual's household income per head in the previous year is in the 75 to $100 \%$ quartile of the sample, zero otherwise. 
Table A1: RE Probit Estimations of Self-reported Retirement without Dynamics (Coefficient Estimates)

\begin{tabular}{|c|c|c|}
\hline \multirow[b]{2}{*}{ Main estimation results } & Coef (z value) & $\begin{array}{l}0 \\
\text { value) }\end{array}$ \\
\hline & & \\
\hline Retired at t-1 & - & - \\
\hline Retired at t-2 & - & - \\
\hline Retired at t-3 & - & - \\
\hline Age 62 to 64 & 1.403 & $(46.80)$ \\
\hline Age 65 plus & 2.497 & (71.39) \\
\hline Female & -0.258 & $(-6.99)$ \\
\hline College & 0.037 & $(0.76)$ \\
\hline Spouse working & -0.439 & $(-10.52)$ \\
\hline Spouse retired & 0.265 & $(7.09)$ \\
\hline Health problem (work limiting) & 0.898 & $(24.73)$ \\
\hline No health insurance & 0.322 & $(8.25)$ \\
\hline Net housing wealth 25 to $50 \%$ & -0.026 & $(0.61)$ \\
\hline Net housing wealth 50 to $75 \%$ & 0.083 & $(1.80)$ \\
\hline Net housing wealth 75 to $100 \%$ & 0.269 & $(5.17)$ \\
\hline Net financial wealth 25 to $50 \%$ & 0.036 & $(1.06)$ \\
\hline Net financial wealth 50 to $75 \%$ & 0.130 & $(3.25)$ \\
\hline Net financial wealth 75 to $100 \%$ & 0.344 & $(7.25)$ \\
\hline Household income per head 25 to $50 \%$ & -0.294 & $(-7.96)$ \\
\hline Household income per head 50 to $75 \%$ & -0.581 & $(-14.18)$ \\
\hline Household income per head 75 to $100 \%$ & -0.831 & $(-18.30)$ \\
\hline Mundlak corrections & & \\
\hline Age 62 to 64 & 0.012 & $(0.10)$ \\
\hline Age above 64 & -0.287 & $(-3.65)$ \\
\hline Spouse working & -0.008 & $(-0.11)$ \\
\hline Spouse retired & -0.008 & $(-0.11)$ \\
\hline Health problem (work limiting) & 0.749 & $(10.98)$ \\
\hline No health insurance & -0.750 & $(-8.11)$ \\
\hline Net housing wealth 25 to $50 \%$ & 0.250 & $(3.07)$ \\
\hline Net housing wealth 50 to $75 \%$ & 0.121 & $(1.40)$ \\
\hline Net housing wealth 75 to $100 \%$ & 0.021 & $(0.22)$ \\
\hline Net financial wealth 25 to $50 \%$ & 0.193 & $(2.10)$ \\
\hline Net financial wealth 50 to $75 \%$ & 0.411 & $(4.43)$ \\
\hline Net financial wealth 75 to $100 \%$ & 0.710 & $(7.04)$ \\
\hline Household income per head 25 to $50 \%$ & -0.072 & $(-0.78)$ \\
\hline Household income per head 50 to $75 \%$ & 0.094 & $(1.02)$ \\
\hline Household income per head 75 to $100 \%$ & -0.355 & $(-3.67)$ \\
\hline Sample size (persons) & \multicolumn{2}{|c|}{$44670(8606)$} \\
\hline Log likelihood & \multicolumn{2}{|c|}{-16440.671} \\
\hline
\end{tabular}

Notes: Omitted reference groups are less than age 62, male, without college education, not married, without work limiting health problem, with health insurance, net housing wealth 0-25\%, net financial wealth $0-25 \%$ and household income per head 0 to $25 \%$. 
Table A2: Dynamic RE Probit Estimations of Self-reported Retirement (Sample from Model 3)

\begin{tabular}{|c|c|c|c|c|c|c|}
\hline \multirow{3}{*}{ Main estimation results } & \multicolumn{2}{|c|}{ Model 1} & \multicolumn{2}{|c|}{ Model 2} & \multicolumn{2}{|c|}{ Model 3} \\
\hline & Coef & ( $\mathrm{z}$ value) & \multicolumn{2}{|c|}{ Coef (z value) } & \multicolumn{2}{|c|}{ Coef (z value) } \\
\hline & & & & & & \\
\hline Retired at $\mathrm{t}-1$ & 1.592 & (55.16) & 1.415 & (48.85) & 1.402 & $(48.50)$ \\
\hline Retired at $\mathrm{t}-2$ & - & - & 0.535 & (17.14) & 0.467 & (15.89) \\
\hline Retired at $\mathrm{t}-3$ & - & - & - & - & 0.199 & (5.21) \\
\hline Age 62 to 64 & 0.796 & (20.57) & 0.707 & (20.33) & 0.763 & (20.30) \\
\hline Age 65 plus & 1.141 & (24.10) & 1.004 & (21.90) & 0.986 & (21.63) \\
\hline Female & -0.145 & $(-5.31)$ & -0.130 & $(-5.05)$ & -0.129 & $(-5.04)$ \\
\hline College & 0.034 & $(0.98)$ & 0.027 & $(0.084)$ & 0.026 & $(0.80)$ \\
\hline Spouse working & -0.206 & $(-3.75)$ & -0.182 & $(-3.37)$ & -0.179 & $(-3.30)$ \\
\hline Spouse retired & 0.139 & (2.99) & 0.140 & (3.05) & 0.142 & (3.09) \\
\hline Health problem (work limiting) & 0.623 & (13.73) & 0.603 & (13.42) & 0.602 & $(13.40)$ \\
\hline No health insurance & 0.250 & (4.78) & 0.263 & (5.10) & 0.265 & (5.15) \\
\hline Net housing wealth 25 to $50 \%$ & 0.069 & $(1.28)$ & 0.086 & $(1.60)$ & 0.089 & $(1.67)$ \\
\hline Net housing wealth 50 to $75 \%$ & 0.020 & $(0.34)$ & 0.030 & $(0.52)$ & 0.031 & $(0.54)$ \\
\hline Net housing wealth 75 to $100 \%$ & 0.118 & $(1.86)$ & 0.094 & (1.49) & 0.087 & (1.39) \\
\hline Net financial wealth 25 to $50 \%$ & 0.056 & $(1.35)$ & 0.065 & $(1.57)$ & 0.066 & $(1.61)$ \\
\hline Net financial wealth 50 to $75 \%$ & 0.176 & (3.58) & 0.191 & (3.93) & 0.195 & $(4.01)$ \\
\hline Net financial wealth 75 to $100 \%$ & 0.366 & (6.38) & 0.378 & $(6.66)$ & 0.383 & $(6.76)$ \\
\hline Household income per head 25 to $50 \%$ & -0.254 & $(-5.29)$ & -0.277 & $(-5.82)$ & -0.280 & $(-5.89)$ \\
\hline Household income per head 50 to $75 \%$ & -0.423 & $(-8.03)$ & -0.435 & $(-8.36)$ & -0.442 & $(-8.49)$ \\
\hline Household income per head 75 to $100 \%$ & -0.631 & $(-10.99)$ & -0.632 & $(-11.14)$ & -0.639 & $(-11.27)$ \\
\hline Mundlak corrections & & & & & & \\
\hline Age 62 to 64 & -0.119 & $(-1.17)$ & -0.129 & $(-0.32)$ & -0.128 & $(-1.31)$ \\
\hline Age above 64 & -0.151 & $(-2.17)$ & -0.178 & $(-2.64)$ & -0.184 & $(-2.73)$ \\
\hline Spouse working & -0.024 & $(-0.33)$ & -0.022 & $(-0.32)$ & -0.023 & $(-0.34)$ \\
\hline Spouse retired & 0.257 & $(4.28)$ & 0.216 & $(3.71)$ & 0.210 & $(3.60)$ \\
\hline Health problem (work limiting) & 0.210 & $(3.40)$ & 0.155 & $(2.59)$ & 0.151 & $(2.52)$ \\
\hline No health insurance & -0.519 & $(-5.51)$ & -0.524 & $(-5.80)$ & -0.529 & $(-5.87)$ \\
\hline Net housing wealth 25 to $50 \%$ & 0.036 & $(0.47)$ & 0.004 & $(0.05)$ & -0.002 & $(-0.03)$ \\
\hline Net housing wealth 50 to $75 \%$ & 0.099 & $(1.28)$ & 0.079 & $(1.04)$ & 0.077 & $(1.02)$ \\
\hline Net housing wealth 75 to $100 \%$ & 0.071 & $(0.87)$ & 0.073 & $(0.92)$ & 0.078 & $(0.97)$ \\
\hline Net financial wealth 25 to $50 \%$ & 0.128 & $(1.72)$ & 0.103 & $(1.44)$ & 0.099 & $(1.38)$ \\
\hline Net financial wealth 50 to $75 \%$ & 0.135 & $(1.74)$ & 0.095 & $(1.28)$ & 0.088 & (1.19) \\
\hline Net financial wealth 75 to $100 \%$ & 0.237 & $(3.04)$ & 0.191 & $(2.33)$ & 0.179 & $(2.19)$ \\
\hline Household income per head 25 to $50 \%$ & 0.037 & $(0.47)$ & 0.066 & $(0.86)$ & 0.064 & $(0.84)$ \\
\hline Household income per head 50 to $75 \%$ & 0.042 & $(0.53)$ & 0.079 & $(1.03)$ & 0.085 & $(1.11)$ \\
\hline Household income per head 75 to $100 \%$ & -0.206 & $(-2.48)$ & -0.132 & $(-1.65)$ & -0.121 & $(-1.50)$ \\
\hline Sample size (persons) & \multicolumn{2}{|c|}{28654 (7023) } & \multicolumn{2}{|c|}{28654 (7023) } & \multicolumn{2}{|c|}{28654 (7023) } \\
\hline Log likelihood & \multicolumn{2}{|c|}{-9208.700} & \multicolumn{2}{|c|}{-9086.466} & \multicolumn{2}{|c|}{-9072.8773} \\
\hline
\end{tabular}

